\title{
RBEP
}

\section{Geografia e poesia}

José Misael Ferreira do Vale

\section{Resumo}

Estabelece relação entre Geografia e Poesia como práticas sociais específicas. O autor demonstra que os poemas têm relações com o contexto e a qualidade de percepção do poeta diante do espaço natural e social. O professor de Geografia poderá explorar com os alunos muitos poemas que permitem estudar as condições históricas e geográficas ligadas ao processo de urbanização e civilização de regiões como as do Estado de São Paulo na segunda metade do século 19 e no início do século 20. O estudo toma como ponto de referência o poema de Rodrigues de Abreu, denominado Bauru, e mostra como a produção poética pode gerar um projeto de ensino que articule as ações pedagógicas de várias áreas de conhecimento ao redor de uma temática comum.

Palavras-chave: educação básica; geografia; poesia; arte e conhecimento; ensino e aprendizagem.

\section{Abstract \\ Geography and poetry}

The article establishes a relationship between Geography and Poetry as specific social practices. The author of the text demonstrates that the poems 
have relationships with the context and the quality of the poet's perception before the natural and social space. The Geography teacher can explore with the students many poems that allow to study the historical and geographical conditions linked to the urbanization process and civilization of areas as the one of the State of São Paulo in the second half of the $19^{\text {th }}$ century and beginning of the $20^{\text {th }}$ century. The study takes as point of reference the poem entitled "Bauru" by Rodrigues de Abreu and displays how the poetic production can generate a teaching project to articulate the pedagogic actions of several knowledge areas around a common theme.

Keywords: primary education; geography; poetry; art and knowledge; teaching and learning.

\section{A especificidade das práticas sociais e suas articulações}

Parece algo inusitado querer estabelecer relações entre poesia ou poema e a Geografia e vice-versa. O poema diz coisas ligadas ao sentimento íntimo da pessoa e à impressão sobre as coisas em geral, acontecimentos e situações vividas por determinado sujeito em circunstâncias às vezes singulares. Em muitos casos um poema pode, mercê da genialidade de seu autor, refletir o sentimento de muitas pessoas e de grupos ideologicamente orientados.

Bertolt Brecht, ${ }^{1}$ por exemplo, tem uma obra ligada umbilicalmente às camadas populares exploradas na "visão de mundo" do dramaturgo alemão. Nesse sentido, a sua poesia faz eco para milhões de pessoas que podem lêla, com prazer, entendendo a sua mensagem. De igual modo, um poeta

${ }^{1} \mathrm{O}$ dramaturgo alemão Eugen Bertolt Friedrich Brecht (18981956), também poeta e teórico de teatro, foi severo crítico do capitalismo, acusado por ele de desnaturalizar a vida social. Ao mesmo tempo tinha a percepção de que "umé nenhum". Só quando "o homem ajudar ao homem" será possível "humanizar a vida" que a competição desenfreada fomentada pelo capitalismo levou à barbárie ao criar multidões de pobres sem condições de existência digna. Em suma, o homem, só, desamparado, será irremediavelmente derrotado, porque não será capaz de lutar contra o sistema dominante. Daí Brecht valorizar a ação política e abominar o "analfabeto político", que não percebe que os problemas humanos são criados por humanos na ânsia de dominação sobre os semelhantes. No plano do teatro, o dramaturgo propôs a noção de "distanciamento" como forma de enxergar objetivamente os problemas sob a óptica dialética. romântico, Castro Alves, pôde narrar a saga dos escravos vindos ao Brasil, nos navios negreiros, com tal poder narrativo-descritivo e sentimental que, em meados do século 19, foi capaz de somar forças ao processo de libertação dos negros que aconteceu legalmente, em 1888, através da Lei Áurea. Os exemplos de relações entre a prática poética e a prática social podem ser multiplicados consultando-se Ferreira Gullar, Vinícius de Morais, Patativa do Assaré, Olavo Bilac, Chico Buarque de Hollanda, Caetano Veloso e muitos outros poetas renomados, cada um com qualidades específicas indiscutíveis e repercussões importantes no plano sociocultural da Nação. Aqui não se trata de fazer juízo de valor sobre a produção de um ou de outro poeta, mas de evidenciar direções distintas em termos de inspiração e "visão de mundo". O poeta é um mensageiro, além de fingidor e cúmplice de uma época.

A Geografia, como ciência, ao contrário da poesia, pretende estudar fenômenos gerais e específicos ligados às pessoas situadas, isto é, pessoas em interação com o espaço físico, com o contexto, num processo dialético de mútua influência, de tal modo que o espaço natural e o social não se separam, mas mantém relação "simbiótica", ou melhor, dialética, entre o humano e o físico-material. Ao estudar um local, região ou território, o 
geógrafo estará atento para o processo de transformação da realidade física pela ação humana e, em casos específicos (a exemplo das erupções vulcânicas), de alterações geradas pela própria natureza ao desalojar e movimentar as pessoas das localidades habitadas originariamente.

As inundações, os tremores de terra, os tornados, etc., são forças naturais que alteram profundamente a vida das pessoas modificando substancialmente o modo de vida das populações e dos lugares. Na interação dialética entre os humanos e a natureza, em muitas oportunidades, o ser humano se vê obrigado a curvar-se diante da realidade rebelde e retirar-se mesmo que temporariamente.

Mas o oposto também é verdadeiro. O ser humano, para sobreviver, precisa aceitar a realidade ambiental que se lhe apresenta e lhe desafia, precisa levar em conta as características físicas de solo, a vegetação, a fauna, o clima, a hidrografia, o índice pluviométrico, a densidade populacional, o tipo de propriedade, o transporte, o grau de instrução dos ocupantes da área, a lavoura e criação de animais da região, etc.

Daí a importância da formação do geógrafo no mundo atual, um estudioso constante do espaço físico-social ${ }^{2}$ que, além de trabalhar com inúmeros saberes, precisa ter capacidade de relacionar esses múltiplos saberes científicos em função de uma reflexão crítica diante da formação econômico-social dominante, chamada capitalismo, que transforma tudo em mercadoria, geradora de lucro e desenvolvimento desigual nem sempre acompanhado de justiça social.

Tarefa nada fácil para o geógrafo, que terá de se haver com o trabalho de realizar a síntese de uma diversidade resultante de múltiplas análises realizadas.

Em relação ao ensino de Geografia, o ponto de partida de um trabalho pedagógico articulado é a prática social geral, rica totalidade de determinações físicas, sociais e culturais. O espaço urbano atual de uma região, território, lugar, cidade tem uma história, uma ocupação social do espaço que é objeto de uma geografia cultural (que reflete a geografia física e social) através da investigação de documentos sobre as transformações físicas, sociais, políticas, educacionais, humanas, ocorridas dialeticamente entre o espaço social e a temporalidade. Num segundo momento metodológico, o professor de Geografia, à vista dos documentos coletados (fotografias, desenhos, pinturas, gravuras, poemas, textos de viajantes, etc.), realizará, por meio de diálogo problematizador, a análise do material escolhido (um poema, uma gravura, uma aquarela, um desenho, etc.) com o objetivo de desenvolver o espírito crítico-reflexivo dos alunos, quando questões conduzirão os esforços de análise da classe. As questões deverão ser de tal ordem que permitam o terceiro momento didático, a apropriação do conhecimento específico (geográfico, geológico, histórico, educacional, etc.), capaz de responder de modo adequado aos quesitos decorrentes do diálogo problematizador. De posse do conhecimento relevante gerado pela leitura, pesquisa e informações outras, será possível à classe chegar ao quarto momento didático, à compreensão sintética da prática social atual como resultado de elementos materiais estruturais e elementos socioculturais próprios de

\footnotetext{
Milton Santos é, sem dúvida, o geógrafo que estudou a fundo questão do espaço. Para ele, o espaço é sempre social. O espaço é síntese de fixos e fluxos; é, em suma, síntese de "sistema de objetos" e "sistema de ações". Os objetos não agem, diz Santos. "São as ações que, em última análise, definem os objetos, dando-lhes um sentido. Mas, hoje, os objetos 'valorizam' diferentemente as ações, em virtude de seu conteúdo técnico. Assim, considerar as ações separadamente não dá conta da sua realidade histórica. Uma geografia social deve encarar de modo uno, isto é, não separado, objetos e ações, 'agindo' em concreto." Podemos dizer que o espaço é um híbrido, síntese do diverso, objetos e ações. Ao interagir com o ambiente, o ser humano transforma a natureza física em natureza social. Os objetos se humanizam e as ações humanas se objetivam.
} 
determinado contexto orientado por fins e valores de determinada formação econômico-social. Em uma palavra: o método que leva ao conhecimento é sempre analítico-sintético. Pela análise chega-se "às primeiras determinações"; pela síntese chega-se à compreensão, que não exclui a explicação, mas vai além, no sentido do entendimento do todo que ultrapassa a simples soma das partes. É o método dialético aplicado à didática e ao ensino.

\section{A travessia de um conteúdo programático a outro ou a importância do diálogo problematizador no processo de articulação do conhecimento relevante}

Se o trabalho do geógrafo é distinto da prática poética, então, como será possível estabelecer a ponte entre a prática poética e a prática geográfica? Como será possível a travessia entre uma prática e outra? Eis a questão que se coloca neste texto.

Tomarei como referência, para responder às questões formuladas, um poema de Benedito Luís Rodrigues de Abreu, nascido em Capivari (SP), em 27 de setembro de 1897, e falecido, em 24 de novembro de 1927, aos 30 anos de idade, na cidade de Bauru (SP).

Ao chegar, em 1922, em terras bauruenses, a impressão primeira da nova terra não era das melhores para o poeta. Em cartas para a noiva, a "Boa Darcy", como sempre abria o texto, em várias oportunidades, referiuse à cidade como um local arenoso. Em carta de 27 de maio de 1924, chega a dizer, no episódio do tenor Otacílio Machado, que faltou ao compromisso assumido com a cidade, ser Bauru "terra de gente sem escrúpulos" ao julgálo companheiro do cantor que lhe havia passado "o conto do vigário", não se apresentando ao público da cidade como lhe prometera.

Entrementes, Rodrigues de Abreu faz amizades na cidade, exerce as funções de escrevente em Cartório de Hipoteca e passa a ter uma vida literária ativa, até que percebe, um pouco tarde, que está condenado, como alguns poetas românticos do século 19 alcançados pela morte prematura causada pela tuberculose. ${ }^{3}$

Nos idos do século 19, vale relembrar, a sina dos poetas românticos era morrer jovem, a exemplo de Casemiro de Abreu, Fagundes Varela e Castro Alves. Casemiro faleceu, em 1860, com vinte e um anos e Castro Alves, em 1871, com vinte e quatro anos, ambos acometidos pela tuberculose. Fagundes Varela faleceu, em 1875, aos trinta e quatro anos, vítima de apoplexia. Infelizmente, naqueles tempos não havia a medicação adequada e nem a medicina especializada que temos hoje, de tal sorte que alguém acometido de tísica era aconselhado a procurar Campos de Jordão (SP) ou alguma região da Europa. Para a cidade paulista foi Rodrigues de Abreu. Depois se instalou em São José dos Campos, passou por Atibaia, para finalmente voltar a Bauru, vindo a falecer, como já se disse, em 24 de novembro de 1927, e ser sepultado no Cemitério da Saudade, na cidade que o abrigou até o derradeiro momento de vida. 
É interessante como Rodrigues de Abreu reage à doença e como revê a impressão inicial em relação à cidade que o acolheu. Ao acabar com o noivado com a "Boa Aracy", afirma categórico, em carta pungente, que "não sabia que estava doente". Diz que só se tocou da situação precária de sua saúde quando, "um dia, depois de uma chuvarada" que lhe atingiu, caiu "com gripe" e passou a ter hemoptises - foi quando sentiu que a morte estava próxima. A consciência de sua finitude e a recusa de sair da vida tão jovem propiciou um dos mais belos poemas da literatura brasileira, segundo avaliação de Carlos Drummond de Andrade e Manuel Bandeira, Casa Destelhada, um primor de composição romântico-modernista.

O poema Casa Destelhada merece ser conhecido por todos os brasileiros. É uma comparação, uma linguagem figurada (tropo), que o poeta faz entre o drama de sua vida e o estado final de uma casa que sofre forte vendaval. O poeta sabe que vai morrer, mas a sua alma não quer abandonar a casa (o corpo) onde outrora fora feliz. Mas sente que não há remédio para sua situação - ele se sente perdido, sem esperança! Nada mais doloroso do que ler o poema, uma vez que, na vida, todos nós teremos um dia a nossa casa destelhada! Podemos dizer que Rodrigues de Abreu é o poeta romântico-modernista da resignação consciente! Isto poderá ser vivenciado pela leitura do poema:

\title{
"Casa Destelhada"
}

A minha vida é uma casa destelhada

por um vento fortíssimo de chuva.

\author{
(As goteiras de todas as \\ misérias \\ estão caindo, com lentidão \\ perversa, \\ na terra triste do meu \\ coração.)
}

A minha alma, a inquilina, está pensando que é preciso mudar-se que é preciso ir para uma casa bem coberta...

(As goteiras estão caindo, lentamente, perversamente, na terra molhada do meu coração.)

Mas a minha alma está pensando

em adiar, quanto mais, a mudança precisa.

Ela quer muito bem a velha casa

em que já foi feliz...

E encolhe-se, toda transida de frio, 


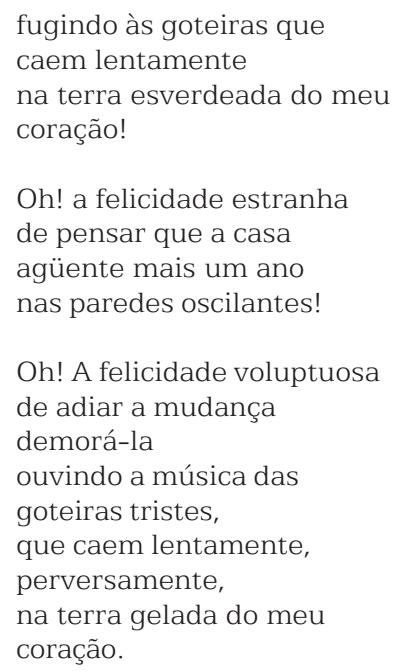

Mas não é esse poema que tomaremos como ponto de análise para evidenciar a possibilidade de articular didaticamente a Literatura, a Geografia, a História e a Educação Artística num trabalho conjunto de ações docentes. A partir do poema "Bauru", Rodrigues de Abreu revê o seu olhar em relação à cidade onde viveu. De repente, o poeta percebe a importância estratégica de Bauru, o seu dinamismo e suas idiossincrasias. O poema começa com versos que demarcam a importância histórica de Bauru. Afirma:

Moro na entrada do Brasil novo.

Bauru! nome-frisson que acorda na alma da gente

ressonâncias de passos em marcha batida

para a conquista soturna do Desconhecido!

Bauru, na última década do século 19 e início do século 20, era "a boca do sertão". Os mapas da época traçavam uma perpendicular que passava por Bauru separando o Estado de São Paulo em duas regiões: a colonizada, dominada pelos brancos, negros e mestiços, e a do sertão, habitada pelos índios caingangues e coroados, entre outros. De um lado a "civilização do café", que vem do Espírito Santo e do Rio de Janeiro, avança pelo Vale do Paraíba e encontra um sertão de terras novas a desbravar. A aristocracia rural exportadora de café carecia de terra "roxa", terra nova para expandir a cultura cafeeira. E a estratégia usada pelos barões do café, "convertidos" à República a partir do governo de Prudente de Morais, é a de utilizar o dinheiro público para abrir as estradas de ferro que, ao mesmo tempo, desbravariam o sertão inóspito, desconhecido, e conquistariam as terras virgens do oeste e noroeste do Estado de São Paulo - Bauru será o ponto de partida da conquista do sertão "desconhecido". É a etnia branca ocupando os espaços em confronto com os caingangues e coroados.

Em 1905 chega à cidade a Estrada de Ferro Sorocabana, ligando Bauru à cidade de São Paulo pelo ramal de Botucatu. Em 1906 começa a abertura da Estrada de Ferro Noroeste, uma iniciativa privada logo federalizada. A seguir, a Companhia Paulista de Estrada de Ferro chega a Bauru. A cidade 
fervilha de trabalhadores ferroviários e não-ferroviários vindos de fora. A agitação é a marca da cidade, que acolhe todo tipo de aventureiro voltado "para a conquista soturna (triste) do Desconhecido". Até perseguidos políticos encontram em Bauru refúgio da polícia, da igreja, do Estado e dos partidos políticos, como o caso dos anarco-sindicalistas, noticiados em $A$ Plebe como refugiados na cidade. Rodrigues de Abreu capta muito bem o momento histórico quando as ferrovias já tinham adentrado o sertão. Tem a percepção histórica e geográfica de que "mora na entrada do Brasil novo" conquistado a ferro e fogo. E a conquista progressiva do noroeste e do oeste paulistas vai abrindo espaço para as fazendas de café, as pastagens e as novas cidades da alta paulista e do noroeste do Estado. Em 1929, a cidade de Cafelândia, no noroeste do Estado, era a maior produtora de café do mundo. No sentido da alta paulista, Garça, Vera Cruz e Alto Cafezal (hoje a cidade de Marília) representavam grandes produtoras de café do Estado. A quebra da Bolsa de Nova York (USA), em 1929, cria as condições políticas para a ascensão da burguesia industrial por meio da Revolução de 1930. Nessa história, Bauru foi o entroncamento ferroviário que transformou o lugarejo, fundado com o nome de Bauru no ano de 1896, em cidade dinâmica, passagem para o "Brasil novo", porta de passagem "para a conquista soturna (sombria) do Desconhecido".

Mas a onda de desbravadores não poupou o ambiente. A derrubada da mata nativa foi quase total, restando hoje apenas alguns exemplares do esplendor vegetal de outrora. O campus da Universidade Estadual Paulista (Unesp) ainda preserva cerca de 200 alqueires paulistas de cerrado nativo. O horto municipal localizado próximo ao Jardim Zoológico da cidade também é área importante, que, aliada à mata do Hospital Lauro de Souza Lima, forma um patrimônio vegetal e animal inestimável em termos históricos, geográficos e de pesquisa e ensino.

Vale observar que numa das avenidas da cidade, a Getúlio Vargas, há um exemplar secular imponente do cerrado brasileiro, a copaíba (Copaifera langsdorfii), árvore frondosa muito procurada por seu óleo tido como medicinal e, por isso, conhecida como pau-de-óleo. O município de Óleo (SP), na Média Sorocabana, deveu o seu nome à enorme copaíba então existente na entrada do vilarejo, derrubada inutilmente por um sitiante, segundo alguns antigos moradores da cidade, ou por forte ventania, segundo outra versão; essa árvore servia de descanso para tropeiros e viajantes que transitavam entre Sorocaba, Conchas, Pereiras, Botucatu, Avaré, Cerqueira César, Santa Bárbara do Rio Pardo, Bernardino de Campos, Santa Cruz do Rio Pardo e Ourinhos - cidades situadas, principalmente as últimas, na região da Média Sorocabana (SP) - com destino ao sul do País. Lembre-se que de 1750 a 1950 tivemos em São Paulo e Estados do sul o ciclo do tropeirismo, o comércio de muares, fruto da iniciativa dos jesuítas das Missões, primeiros criadores de híbridos na região cisplatina, onde os compradores de Sorocaba e região iam buscar mulas e burros para venda e troca.

Rodrigues de Abreu diz: 
Acendi meu cigarro no toco de lenha deixado na estrada,

no meio da cinza ainda morna

do último bivaque dos Bandeirantes.

A visão impressionista do poeta capivarano não deixa de registrar a derrubada da mata nativa, numa época em que "civilizar" era arrasar as matas (como se faz até hoje), já que a floresta era o local de morada do bugre que resistia ao domínio de suas terras, um empecilho ao desenvolvimento da atividade cafeeira e pastoril. Rodrigues de Abreu constata que a derrubada da mata nativa (documentada por fotografias do início do século 20), certamente indiscriminada, acabava com o "último bivaque dos Bandeirantes", isto é, o desmatamento intensivo acabava com as árvores frondosas, como a copaíba, que outrora serviram de abrigo e de pernoite aos bandeirantes, aventureiros, tropeiros e militares. E o desmate da região de transição entre a mata atlântica e o cerrado brasileiro propriamente dito era acompanhado pela prática de atear fogo à galhada cortada. E no começo do século, Bauru era "a entrada do sertão", caminho natural para Mato Grosso do Sul, Paraguai e Bolívia. A abertura da Estrada de Ferro Noroeste foi uma frente de trabalho e de batalha no sentido da conquista do espaço físico ocupado pelos índios da região, que foram dizimados ou empurrados para outras regiões do Estado e do País. Mas o poeta, que ao chegar a Bauru só percebia a precariedade do local, longe da vida urbanizada de Capivari (SP), agora, doente, percebe que a cidade cresce rapidamente e o impressiona, quando declara:

Cidade de espantos!

Carros de bois geram desastres com máquinas Ford!

Rolls-Royces encalham beijando a areia!

Casas de tábuas mudáveis nas costas;

bungalows comodistas roubados da noite para o dia, às avenidas paulistas...

O poeta se espanta com Bauru do começo do século 20; uma cidade com pouco mais de 25 anos cheia de contrastes. Nela acontecem fatos inusitados quando um Ford T, conhecido no Brasil como "pé-de-bode" ou "Ford de bigode", é abalroado por um carro de boi e as suas ruas prendem automóveis Rolls-Royces atolados, até os eixos, na areia resultante de um solo sem proteção vegetal, falto de material argiloso, que no decorrer das chuvas gera os sedimentos de arenito, sempre em grande quantidade, após cada temporal. O ritmo frenético de cidade em crescimento propicia o frenesi de construções de alvenaria e de madeira, muitas em estilo bangalô, que fazem lembrar as residências da capital paulista - em suma, a cidade cresce e gradativamente se urbaniza. As fotografias existentes sobre aquela época evidenciam a transformação dialética do espaço físico em espaço social mediado pela presença humana. A mão humana, através do trabalho, gera uma nova realidade ao confrontar-se dialeticamente com a realidade físico-natural. O ser humano altera a natureza e lhe dá a marca própria de suas necessidades.

Mas é preciso que a pessoa carente tenha o mínimo para poder ser. Ninguém poderá ser sem ter o essencial na luta pela existência. Como diz 
célebre filósofo, ${ }^{4}$ é preciso, em primeiro lugar, comer, beber, vestir, calçar, morar, trabalhar para poder fazer história. E, certamente, a moradia, o trabalho e o dinheiro constituem fatos milenares que possibilitaram, em todo mundo, o aparecimento de civilizações e das cidades como Bauru. As entradas, bandeiras e monções, no Brasil, por exemplo, seguiam os cursos de água, em especial os rios Tietê e Paraná. Eram movidas primeiramente pela tarefa de apresamento de índios para o trabalho escravo nos engenhos de açúcar, posteriormente substituídos pelos negros vindos da África para trabalho na mineração e nas lavouras de café.

As gravuras de Rugendas e Debret são muito instrutivas como documentos do Brasil anterior à República; deveriam ser objeto de análise cuidadosa por partes dos professores de Geografia, História e Artes. ${ }^{5}$ Elas registram momentos importantes da história do País. Materializam, através do desenho e da cor, a leitura da realidade feita por artistas num dado momento espaço-temporal.

Rodrigues de Abreu volta a se espantar com a Bauru de 1925-1927, e registra, por meio de sua poesia, a vida urbana da cidade:

Cidade de espantos!

Eu canto a estesia suave dos teus bairros chics

as chispas e os ruídos do bairro industrial,

a febre do lucro que move os teus homens nas

ruas do centro

e a pecaminosa alegria dos teus bairros baixos...

Recebe o meu canto, cidade moderna!

O poeta deixa transparecer as diferenças sociais entre a estesia, isto é, o sentimento de beleza, dos bairros nobres que afloram na cidade em contrapartida à pecaminosa alegria dos bairros populares, onde a população pobre da periferia urbana procura sobreviver. Há indisfarçavelmente um pré-juízo em relação às camadas populares ("bairros baixos") que se vêm obrigadas a morar afastadas do centro da cidade. Percebe o poeta que a cidade que cresce e se desenvolve aos poucos se industrializa para dar conta das exigências da própria urbanização.

Aparecem os comerciantes, os serralheiros, os ferreiros, os mecânicos, os fundidores, os funileiros, os soldadores, os pedreiros, os engenheiros, os professores, os médicos, os fotógrafos, os religiosos, os ferroviários de manutenção de locomotivas a vapor e vagões de carga e passageiros da Estrada de Ferro Noroeste (NOB), só para ficarmos na citação das profissões citadinas. O poema quer mostrar a diversidade de papéis e funções que uma cidade moderna vai progressivamente criando à medida que ocorre seu desenvolvimento econômico-social. A "febre de lucro" evidencia que o capitalismo, na sua forma industrial-comercial de compra e venda de mercadorias, ${ }^{6}$ movimenta as ruas do centro. Os automóveis se incorporam à paisagem urbana. É preciso lucrar para entesourar ou investir. Os revendedores de automóveis, importados e montados no Brasil, criam as condições para a abertura e melhoria das estradas. A "jardineira" substitui, gradativamente, o trole, a carruagem rústica de outrora, puxada por cavalos.
${ }^{4}$ Em A ideologia alemã, Marx e Engels fazem a primeira investida contra o "domínio do pensamento puro" que dominava a Alemanha logo após a morte de Hegel. Ambos fazem a crítica dos velhos e jovens hegelianos. A idéia de inversão aparece em Feuerbach, quando este filósofo hegeliano parte do pressuposto de que o homem faz a religião e de que a idéia de que Deus fez o homem é a marca da inversão. A partir de 1845 Marx e Engels percebem que não se trata, como no caso dos jovens hegelianos, de combater idéias errôneas. Os verdadeiros problemas humanos não são a adoção delas, mas não se aperceber das contradições reais que geram tais idéias. Os jovens hegelianos (Max Stirner, Bruno Bauer, Feuerbach) querem lutar contra a fraseologia, a mera abstração. "Esquecem, entretanto, que eles mesmos não lhe opõem senão outra fraseologia, e que não lutam, absolutamente, contra o mundo que realmente existe, combatendo, assim, apenas a fraseologia desse mundo" (Marx, Engels, 1965, p. 14).

${ }^{5}$ Ainda não percebemos, como educadores, a importância da prática artística no trabalho educativo das escolas públicas. A gravura, a pintura, a escultura, a fotografia, a aquarela, a xilogravura, o grafite, o filme, a revista, o jornal, etc., são manifestações artístico-culturais que permitem a leitura da realidade material e social de maneira direta ou indireta. Há relação estreita entre a prática social ea prática artística, de tal modo que os professores de Português, Geografia e História não podem deixar de utilizar os recursos audiovisuais para enriquecer e tornar menos árdua a tarefa de transmitir a cultura acumulada pela humanidade ao longo de sua prática histórico-social. É, por exemplo, muito instrutivo o olhar estrangeiro sobre a nossa realidade natural e social através dos artistas viajantes que viram sem pré-juízo os indígenas, negros e gente do povo. $\hat{E}$ o caso de Debret, Rugendas, Johann Baptist von Spix, Karl Philipp von Martius e outros, que retrataram com minúcias o ambiente presenciado em terras brasileiras.

${ }^{6}$ Como valor de uso, a mercadoria tem existência milenar. Marx (2004, p. 57), ao tratar da formação econômico-social chamada capitalismo, afirma: "A riqueza das sociedades onde rege a produção capitalista configura-se em 'imensa acumulação de mercadorias', e a mercadoria, isoladamente considerada, é a forma elementar dessa riqueza. Por isso, nossa investigação começa com a análise da mercadoria.". Marx evidencia que a mercadoria além de seu valor de uso tem um valor de troca, que é o poder de uma mercadoria obter certa quantidade de outras mercadorias 
Convive-se com o novo e o antigo, mas a cidade vai absorvendo o "espírito da modernidade".

E esta agitação própria da cidade em crescimento impressiona o poeta, que faz uma oportuna interrogação:

Onde é que estão, brasileiros ingênuos,

As úlceras feias de Bauru?

Vi homens fecundos que fazem reclamos da Raça!

E eu sei que há mulheres fidalgas que ateiam incêndios

na mata inflamável dos nossos desejos!

Mulheres fidalgas que já transplantaram

o Rio de Janeiro para este areal...

Rodrigues de Abreu lembra a fama de Bauru. No começo do século, quando alguém dizia que viria para Bauru, ficava uma suspeita no ar. Estaria a pessoa com lepra ou com a úlcera de Bauru? O seu destino era o tratamento no hospital de Aimorés, que tratava, naquela época, de doenças da pele. Hoje, o Hospital Lauro de Souza Lima, criado em 1933, é referência internacional em termos de hanseníase e outras doenças dermatológicas. Sabe-se que outrora, no final do século 19, a abertura da mata em várias regiões do País coincidiu com o aparecimento do pênfigo ou "fogo-selvagem", denominação comum a inúmeras dermatoses de aspecto impressionante. Em 1925-1927 Rodrigues de Abreu se lembra da doença e, num desafio, pergunta onde estão as "úlceras feias de Bauru" e defende a cidade dizendo que vê nas ruas e em todos os lugares homens com saúde que não desmerecem a raça. De igual modo, as mulheres são fidalgas que ateiam fogo nos nossos melhores desejos; mulheres tão especiais que "já transplantaram o Rio de Janeiro para este areal". É possível que Rodrigues de Abreu estivesse se referindo às mulheres e filhas das classes média e alta que, por necessidade ou aventura, como no caso de dirigentes, engenheiros e funcionários públicos dos governos federal e estadual indicados para os cargos da administração pública, tiveram que se abalar para "a boca do sertão"; ou, no caso dos donos de empreendimentos privados, sempre ávidos de lucro, que viam na cidade uma promessa de retorno fácil do investimento aplicado. Quem sabe da verdade? Mera suposição. Mas o certo é que havia mulher interessante na praça, como se diz popularmente, a ponto de aguçar a imaginação do poeta romântico-modernista. E como o Rio era a capital federal, o centro mais evoluído do Brasil na década de 20, era natural que o padrão de beleza feminina tivesse como imagem a mulher da capital do País.

É importante ressaltar novamente que Rodrigues de Abreu, desde o valor dinheiro (Mercadoria-Dinheiro-Mercadoria). No capitalismo, a produção de mercadorias gera mais produção de mercadorias, assim como o dinheiro gera mais dinheiro através do lucro conseguido por meio da compra do trabalho humano assalariado, a única mercadoria que o pobre pode, sob certas condições, negociar com aquele que detém o capital, o dono do dinheiro excedente. primeiro momento em que chegou a Bauru, ficou impressionado com a areia das ruas ainda não calçadas; só em 1924 começaria o calçamento do centro da cidade. Em várias oportunidades ele cita o fato de Bauru ser um lugar arenoso que dificultava o trânsito. São a impressão geográfica mais precário, com o atual, urbanizado, por meio do cotejo de imagens. Hoje, com 110 anos de existência, Bauru cresce e merece o epíteto de "a cidade forte e o registro histórico mais evidente que permitem comparar o antigo, 
sem limites", apesar dos inúmeros problemas que se multiplicam em decorrência de seu próprio crescimento.

Rodrigues de Abreu percebe, também, o lado alegre da cidade que se desenvolve:

A Alegria buzina e atropela os trustes nas ruas.

A cidade se fez a toques de sinos festivos,

a marchas vermelhas de música, ao riso estridente,

de Colombinas e de Arlequins.

Há nestes versos fatos compreensíveis e outros que exigiriam pesquisa histórica.

O primeiro verso soa hoje como algo estranho. A Alegria seria a marca da cidade que atropela a seriedade das empresas? Será isso? Não sabemos. Por que a palavra truste? Significa algum posicionamento político do poeta? Não há como saber pela simples leitura do poema. Outro ponto para pesquisa histórica. Mas o poeta esclarece que "a cidade se fez a toque de sinos festivos", isto é, através de festas religiosas, com certeza, que antigamente compreendiam procissões quilométricas, casamentos, leilões e quermesses, festas juninas e natalinas - marcas da religiosidade do povo de antanho. É bom frisar que, na década de 20 do século passado, religiosas católicas chegam a Bauru e iniciam projeto educacional, de caráter confessional, instalando primeiramente o externato São José, embrião de futuro colégio e da atual Universidade do Sagrado Coração.

Rodrigues de Abreu alude também ao fato de que na cidade havia apresentação de "marchas vermelhas de música". Por que o qualificativo "vermelho"? Outro ponto de interrogação. Estaria ele se referindo aos movimentos políticos da década de 20, em especial ao "movimento tenentista" ou mesmo à coluna Prestes? - é preciso lembrar que o Partido Comunista se organiza em 1922 - ou simplesmente às bandas ou liras musicais em suas retretas em praça pública, executando marchas militares tão a gosto do povo. Questões para historiadores. Mas, com certeza, os carnavais de rua e de salão deveriam ser animados naquela época para receberem a menção do poeta, personificados nas figuras de Colombinas e Arlequins. Tudo isso mostra a vida cultural da novel cidade e o ambiente político que se tornará agudo no período 1929-1930, com o avanço do "movimento getulista", quando dois jornais da cidade foram "empastelados"7 pelos getulistas bauruenses e o governo do Estado receberia interventor designado pelo movimento revolucionário. O poeta, entretanto, não viveu o suficiente para ver as mudanças políticas e o fim da Primeira República, dominada pela aristocracia rural exportadora de café e sustentada pela "política café-comleite" montada pelo Partido Republicano paulista e mineiro. Não é sem razão que o ramo de café faz parte das Armas da República.

Não foi possível, entretanto, investigar a ideologia política do poeta. Outro ponto que mereceria investigação séria de algum historiador seria a sua filiação política, embora tudo pareça indicar sua adesão ao pensamento dominante.
${ }^{7}$ O Correio de Bauru e o Diário da Noroeste, jornais de Bauru, foram "empastelados" pelos simpatizantes bauruenses da Revolução de 1930. Anteriormente, em 1924, a cidade de Bauru virara praça de guerra ao ser ocupada pelos revoltosos comandados por Isidoro Dias Lopes. Há registros fotográficos dos acontecimentos. 
A homenagem a Bauru continua pela verve do artista que agora se expõe, pessoalmente, afirmando:

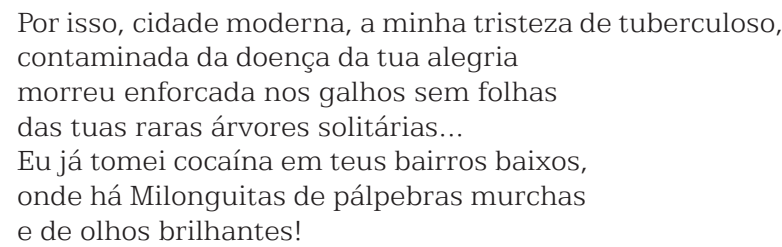

A tuberculose abate o poeta e o entristece porque a cidade moderna, alegre, não lhe permite usufruir de seu encanto. Abatido, procura o narcótico e a freqüência em casas de dançarinas (?) onde pode passar momentos de refúgio à desdita, lugares certamente reprovados pela sociedade religiosa da época, sempre vigilante em termos de "proteção à família e aos bons costumes".

Com a sensação de rejeição, quando os pais da noiva exigem a interrupção do noivado com a sua "Doce Aracy", Rodrigues de Abreu, solteiro e abatido, não vê saída e procura o caminho do entorpecente e da satisfação pessoal que não encontraria, certamente, na sociedade conservadora que, então, se firmava na região. Diante de tanta desgraça não há como censurálo, embora o caminho da droga seja uma rota arriscada e, muitas vezes, sem volta. O que fica claro, mediante registro do poeta, é que a venda de narcóticos é coisa antiga e quase sempre ligada ao lenocínio. Que fazer quando a pessoa perde o maior valor, a própria saúde?

Deixando o drama pessoal, "a tristeza de tuberculoso" que sente a alegria da cidade, mas vê o fim próximo do corpo combalido, o poema volta a exaltar a cidade:

Rua Batista de Carvalho!

O sol da manhã incendeia ferozmente

a gasolina que existe na alma dos homens.

Febre....Negócios...Cartórios, Fazendas...Café... (sic)

Mil forasteiros chegaram com os trens da manhã.

e vão, de passagem, tocados da pressa,

para o El-Dourado real da zona noroeste!

É interessante observar que, no começo do século 20, a rua que dera início ao município fora a Araújo Leite, na direção da atual Baixada do Silvino, saída, na ocasião, para os sítios, fazendas das adjacências do povoado e da Vila de Pederneiras. A rua fora homenagem ao primeiro Juiz de Paz do Distrito de Bauru, João Baptista de Araújo Leite. Ele e Azarias Leite, em 1883, conseguiram, com a ajuda de influentes políticos de São Paulo, a criação do Distrito de Paz da cidade. Dizem os historiadores que a pretensão contou com a séria oposição de Lençóis (Paulista) e do distrito do Espírito Santo de Fortaleza, próxima ao povoado de Bauru. Em 30 de agosto de 1893, em plena República, o Dr. Bernardino de Campos, presidente do Estado de São Paulo, promulgava a Lei no 209, que criava o Distrito de Paz da povoação de Bauru, instalado em 7 de julho de 1884, anexa ao município da 
vila de Fortaleza. Posteriormente a luta política entre Fortaleza e Bauru se intensificou, até que o então presidente (governador) do Estado de São Paulo, Dr. Manoel Ferraz de Campos Salles, sancionou a Lei n ${ }^{\circ} 328$, de $1^{\circ}$ de agosto de 1896, do Congresso do Estado (Assembléia Legislativa), com um único parágrafo - O município de Espírito Santo da Fortaleza passa a denominar-se Bauru, mudando-se a sua sede para esta última povoação-, fim de um embate político que decreta a decadência da povoação do Espírito Santo de Fortaleza. Nasce a autonomia política da cidade de Bauru.

Na década de 20, com o crescimento acentuado de Bauru, a Rua Batista de Carvalho, perpendicular à Rua Araújo Leite, transforma-se em centro comercial, religioso e de lazer, com a construção da praça da cidade no começo do século 20. É o centro nervoso da cidade, onde a vida econômica acontece, os negócios são realizados, os cartórios lavram escrituras, onde o café do município, em especial, da Fazenda Val de Palmas, é negociado e levado para o porto de Santos. A rua é a passagem de forasteiros que diariamente chegam a Bauru e tomam o rumo do "El-Dourado real da zona noroeste" ou retornam do fundo do sertão com destino a São Paulo. Bauru é o ponto de convergência dos forasteiros que passam e dos que ficam e criam raízes na terra branca.

As estações ferroviárias, na primeira década do século 20, fervilham de aventureiros (muitos italianos, portugueses, japoneses e espanhóis) que se arriscam carregando as malas nas costas à procura de oportunidades nas cidades que vão despontando à medida que os trilhos da Sorocabana, Noroeste e Paulista serpenteiam, através dos espigões, no sentido da Alta Sorocabana até Porto Epitácio, chegando a Cuiabá, em Mato Grosso, e à Bolívia, no caso da NOB, e, através da Companhia Paulista de Estrada Ferro, à Alta Paulista, até atingir, mais tarde, as barrancas do Rio Paraná, em Panorama, todos impulsionados pelo lucro do café e pela oportunidade de trabalho na lavoura cafeeira, exigente de muita mão-de-obra. É a civilização do café que cria cidades no interior do Estado de São Paulo. E o poeta conclui o poema "Bauru", fatigado, mas esperançoso:

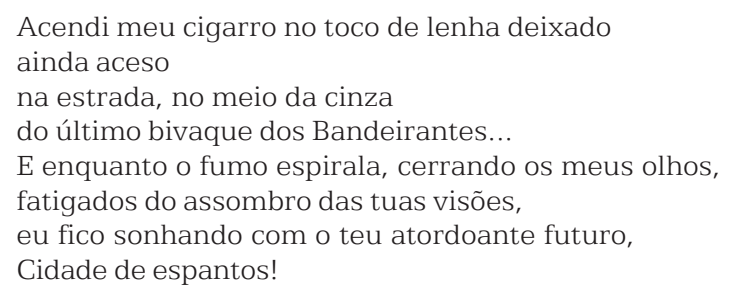

O poeta, com "olhos fatigados", prevê o grande futuro de Bauru. Sonha com uma cidade moderna, com certeza, cheia de contrastes e espantos. Parece que o futuro veio a se confirmar com a presença de sua atual importância no contexto do Estado de São Paulo. Basta lembrar que a maioria dos caminhos passa, hoje, por Bauru. Nada mal para o prestígio dos poetas, que comumente são julgados como sonhadores desgarrados da realidade. Em Rodrigues de Abreu o sentimento e a consciência da realidade andam de mãos dadas... Em uma de suas cartas ele faz a seguinte assertiva: "Nesta 
terra de progresso e agitação, tenho em minhas mãos o futuro. Não serei eu quem vá apodrecer meus dias aí em Capivari." Preferiu ficar em Bauru a voltar para a terra natal. Bauru conquistara o poeta! E o poeta imortalizava a cidade!

\section{A apropriação do conhecimento e a síntese compreensiva}

O poema Bauru, de Rodrigues de Abreu, abre possibilidades de trabalho articulado de várias disciplinas escolares.

Os assuntos são de várias ordens que exigem a existência de um projeto pedagógico que venha a articular, de maneira orgânica, ${ }^{8}$ diferentes disciplinas formais, como Língua Portuguesa, Geografia, História e Artes, por exemplo. A questão prévia decisiva é saber quais professores poderão sentar-se ao redor de uma mesa para planejar as atividades de forma coerente e articulada, os conteúdos programáticos de cada disciplina acerca de um assunto comum que deverá ter olhares e leitura diferentes, mas complementares entre si, tarefa nada fácil numa formação política e econômicosocial centrada no individualismo e na filosofia barata de "cada um por si e Deus para todos" que impera nas sociedades competitivas de natureza capitalista. É um desafio enorme quebrar o individualismo pedagógico e gerar o trabalho coletivo entre professores e alunos na escola pública brasileira.

Um poema como o analisado neste texto exige, em primeiro lugar, que professor e aluno contextualizem a criação artística; o primeiro momento didático seria, sem dúvida, o da contextualização da obra de arte. A obra de arte reflete o seu tempo e o seu espaço social. A análise interna de um poema, para ser fidedigna, deve se articular dialeticamente à análise externa. Como afirma Antonio Cândido (1976) em Literatura e sociedade, só podemos entender uma obra de arte, no caso específico o poema Bauru, "fundindo texto e contexto numa interpretação dialeticamente íntegra".

Num segundo momento, após a análise interna e externa do texto, professor e aluno realizariam o diálogo problematizador, como propõe Paulo Freire (1996) em Pedagogia da autonomia, quando o educador e o educando determinam em conjunto o sentido e o significado do saber científico

${ }^{8}$ O projeto pedagógico deveria ser a tomada de posição da escola em relação ao trabalho a ser desenvolvido com a comunidade em termos de escolarização básica. A idéia de projeto (pro-jectu) é a de um "lançar-se à frente", pensar no futuro preparando-o no presente através de planejamento prévio da ação. Não se projeta para o presente imediato, mas para o futuro próximo, mediato. No plano do ensino, o projeto significa atuar coletivamente de modo que os alunos tenham, ao mesmo tempo, a visão particular dos problemas e a visão geral dos assuntos abordados sob múltiplas perspectivas. que flui da prática social geral, pois "tudo poderá ser problematizado". Alunos e professor, após a análise da obra de arte, poderiam problematizar o poema formulando questões atinentes à Geografia, à História, à Geologia, à Economia, à educação e outras práticas sociais, como sugerem as questões abaixo:

a) A ocupação do espaço físico significa a ocupação histórica do espaço pelo ser humano? É impossível separar o espaço social da construção de sua história no tempo?

b) A ocupação do espaço físico é inseparável da violência histórica pela conquista da terra? (Lembre-se que, em 1901, o Monsenhor Claro foi morto pelos índios caingangues que defendiam o seu espaço de vida). 
c) A ocupação do espaço físico se faz, dialeticamente, em função de interesses e necessidades do ser humano? É correto dizer que o espaço físico adquire a dimensão social pela via do trabalho humano?

d)O indivíduo humano confere uma qualidade social ao espaço físico conforme a sua inserção na formação econômico-social? Em uma sociedade escravocrata a mentalidade dominante é escravagista? Numa sociedade republicana as idéias dominantes são as idéias da classe dominante?

e) O trabalho humano é o elemento que cria valor transformando, dialeticamente, o espaço físico em espaço social? Numa formação econômico-social dominante, como a capitalista, a mercadoria é a base do sistema? Como acontece a produção, o consumo e a circulação da mercadoria nos dias atuais?

f) Que fatores influem no desenvolvimento de uma cidade?

g) A posição geográfica de um lugar favorece o seu desenvolvimento?

h) As fotografias e os desenhos ajudam a compreender o desenvolvimento de uma cidade. As representações artísticas congelam a realidade social em momentos determinados e, assim, permitem a avaliação das transformações em geral ocorridas ao longo da dimensão espaço-temporal. Analise o suplemento "Bauru Ilustrado" e descreva a cidade de ontem em comparação com a atual.

i) A história é construída por homens num espaço físico-social. Analise a afirmação.

j) A leitura de jornais de época faz sentido na reconstrução do passado e compreensão do presente?

k) As ferrovias foram estratégias de governo (paulista e federal) para a ocupação do espaço físico-natural na direção do norte do Paraná e sul de Mato Grosso. O Estado brasileiro foi a base para a expansão privada da cultura do café?

l) Após a chegada da indústria automotiva no País, a estratégia governamental foi substituir a ferrovia pela rodovia. As privatizações das empresas estatais correspondem ao ideário neoliberal de diminuir a influência do Estado na economia e aumentar o poder econômico de grupos alinhados ao capitalismo internacional. A afirmação final é correta ou incorreta? Comente.

m) Os poemas são impressões individuais que podem carregar impressões geográficas e históricas. Pesquise na literatura brasileira exemplos narrativos/descritivos de produções artísticas que evidenciam impressões temporais e espaciais.

n) O grafite e a pintura são meios legítimos de registrar a história e a geografia de um lugar. O muro da escola deveria registrar poemas e suas representações pictóricas feitas por alunos após o desenvolvimento do projeto pedagógico coletivo. É possível usar a arte para registrar e avaliar o conhecimento?

o) Como seria, afinal, um poema dedicado à cidade de Bauru de nossos dias? Tente compor um texto articulando o conhecimento acumulado em decorrência do estudo feito do poema Bauru. 
Outras questões poderiam ser alvo do diálogo problematizador entre o professor e a classe. Volto a dizer que o professor deve tomar a prática social como ponto de partida e de chegada do método de ensino, conforme advogam Saviani (2002) e Gasparin (2002), e utilizar o diálogo problematizador, proposto por Paulo Freire (1996), como recurso didático para conduzir os alunos ao terceiro momento, a apropriação de conhecimentos específicos, que, articulados, permitirão a elaboração de sínteses cada vez mais complexas da realidade econômico-social numa dimensão cultural que incluirá, certamente, a visão geográfica e histórica da realidade. A educação escolar deverá, portanto, articular, dialeticamente, a) conteúdos, b) métodos, c) contexto, d) fins e valores, como afirma Ferreira do Vale (1998), com a preocupação de realizar a síntese do objetivo e do subjetivo através do processo dialético de análise e síntese, base de todo conhecimento possível. Se chegarmos a tanto, o aluno será o grande beneficiado.

\section{Referências bibliográficas}

BOTTOMORE, Tom et al. Dicionário do pensamento marxista. Rio de Janeiro: Jorge Zahar, 1988.

BRECHT, Eugen Bertold Friedrich. O teatro de Bertold Brecht. Rio de Janeiro: Civilização Brasileira, 1977 e 1978. (Vários volumes)

CANDIDO, Antonio. Literatura e sociedade: estudos de teoria e história literária. São Paulo: Nacional, 1976.

FERREIRA DO VALE, J. Misael. Projeto político-pedagógico como instrumento coletivo de transformação do contexto escolar. In: BICUDO, Maria Aparecida Viggani; SILVA JÚNIOR, Celestino Alves da (Org.). Formação do educador e avaliação educacional. São Paulo: Ed. Unesp, 1999. v. 1.

Breves anotações sobre a prática alfabetizadora. Revista Nuances, Presidente Prudente, v. 4, n. 4, 1998.

FREIRE, Paulo. Pedagogia da autonomia: saberes necessários à prática educativa. São Paulo: Paz e Terra, 1996.

GASPARIN, João Luiz. Uma didática para a pedagogia histórico-crítica. Campinas: Autores Associados, 2002.

MARX, K.; ENGELS, F. A ideologia alemã. Rio de Janeiro: Zahar, 1965.

MARX, Karl. O capital. Rio de Janeiro: Civilização Brasileira, 2004. 
MATTOS, Carlos Lopes de. Vida, paixão e poesia em Rodrigues de Abreu. Capivari: Gráfica e Editora do Lar/ABC do Interior, 1986.

RODRIGUES DE ABREU, Benedito Luiz. Casa destelhada. Bauru: Jalovi, 1986.*

SANTOS, Milton. A natureza do espaço. Técnica e tempo. Razão e emoção. São Paulo: Hucitec, 1996.

SAVIANI, Dermeval. Escola e democracia. Campinas: Autores Associados, 2002.

SILVA RAMOS, Frederico José da. Grandes poetas românticos do Brasil. São Paulo: Edições LEP, 1952.

SOUZA, Álvaro José de. Geografia lingüística: dominação e liberdade. São Paulo: Contexto, 1991.

José Misael Ferreira do Vale, doutor em Filosofia da Educação pela Pontifícia Universidade Católica de São Paulo (PUC-SP), é professor assistente do Departamento de Educação da Faculdade de Ciências da Universidade Estadual Paulista (Unesp), Campus de Bauru (SP).

jmisael.vale@terra.com.br

Recebido em 11 de janeiro de 2007.

Aprovado em 8 de junho de 2007
* Esta obra reúne textos de diferentes épocas, a saber: Lâmpada inquieta (Capivari, 1921), Quarto de doente (Campos de Jordão, 1925), Cadeira de lona (São José dos Campos, 1925) e Macega florida (Bauru, 1926). Em 1919 Rodrigues de Abreu publicara o texto Noturnos e, em 1924, A sala dos passos perdidos. 